Letrônica, Porto Alegre, v. 7, n. 2, p. 966-988, jul./dez., 2014

\title{
A ENCENAÇÃO REPRESENTADA NO (DIS)CURSO DE UMA RETIRADA: MORTE E VIDA SEVERINA
}

\author{
THE STAGING REPRESENTED IN THE (DIS)COURSE OF A MIGRATION: \\ MORTE E VIDA SEVERINA
}

Elisabete Alfeld ${ }^{*}$

\begin{abstract}
Resumo: Em Morte e Vida Severina a retirada é contada em versos. Dezoito sequências-cenas sugerem uma forma de encenação que se manifesta na textualidade da linguagem. 0 objetivo norteador das considerações apresentadas consiste em destacar os recursos estéticos que sugerem a encenação da retirada construída no espaço poético da escritura. Para isso, ressaltamos, no primeiro momento da análise, os traços constitutivos da poética da retirada para, em seguida, apresentar como essa modalidade de encenação é representada no (dis)curso de uma retirada.
\end{abstract}

Palavras-chave: Retirada; Escritura poética; Encenação.

\begin{abstract}
In Morte e Vida Severina the migration is told in verse. Eighteen scenes- sequences suggest a form of staging that is manifested in the textuality of the language. The objective of the considerations presented consists of highlighting the aesthetic features that suggest the staging of the migration in the poetic space of scripture. To this end, we emphasize, in the first moment of analysis, the traces constituting the poetics of migration, then presenting how this form of staging is represented in the (dis)course of a migration.
\end{abstract}

Keywords: Migration; Poetic writing; Staging.

\section{Introdução}

Várias são as histórias de viagens cantadas e contadas. A temática do deslocamento do homem em busca de outros lugares geográficos ou imaginários adquire conotações diversas. Na literatura, quase sempre, as histórias de viagens são desencadeadas pela situação conflituosa que envolve o homem e o meio ambiente físico e/ou social. Algumas vezes, a viagem é uma metáfora, uma saída imaginária como a contada em versos por Manuel Bandeira:

\footnotetext{
* Doutora em Comunicação e Semiótica pelo Programa de Estudos Pós-graduados em Comunicação e Semiótica, PUCSP. Professora do Departamento de Arte, da Faculdade de Filosofia, Comunicação, Letras e Artes da Pontifícia Universidade Católica de São Paulo.
} 
Vou-me embora pra Pasárgada

Lá sou amigo do rei

Lá tenho a mulher que eu quero

Na cama que escolherei

Vou-me embora pra Pasárgada

Vou-me embora pra Pasárgada

Aqui eu não sou feliz. (BANDEIRA, 2009, p.29).

Nos versos de Bandeira, a intenção da viagem é metaforizada, o deslocamento do homem é para uma cidade-paisagem-fabulosa: "onde podemos viver pelo sonho o que a vida madrasta não nos quis dar." (BANDEIRA, 2009, p.13). 0 'motivo' da viagem é o desencanto, retirar-se do mundo para realizar-se no sonho. Bandeira espacializa poeticamente essa modalidade de retirada, propõe a saída metafórica como mediação entre o desencanto da vida e o encantamento do sonho.

Algumas vezes, a viagem teve (e ainda tem) um lugar-destino prontamente identificável: a Região Sudeste. Por exemplo, é essa a saída proposta por Conceição, protagonista do romance $O$ Quinze, a Chico Bento:

\footnotetext{
— Por que vocês não vão para São Paulo? Diz que lá é muito bom... Trabalho por toda parte, clima sadio... Podem até enriquecer...

0 vaqueiro levantou os olhos, e concordou, pausadamente:

- É... Pode ser... Boto nas suas mãos, minha comadre. 0 que eu quero é arribar. Pro Norte ou pro Sul...

[...]

Conceição levantou-se, rebatendo o vestido:

- Pois então está dito: São Paulo! Vou tratar de obter as passagens. Quero ver se daqui a alguns anos voltam ricos...

[...]

E despedindo-se, Conceição saiu vagarosamente, pensando que poderia dar bom impulso à roda daqueles destinos, levando-os a um caminho melhor, mais suave e mais largo... (QUEIROZ, 1993, p.107).
}

As migrações, contadas na literatura, têm destinos múltiplos, assim como são múltiplos os agentes que determinam a retirada: o deslocamento realizado no percurso de uma travessia imaginária ou geográfica. Das migrações motivadas pelas adversidades do sertão nordestino contadas na literatura, duas das histórias são paradigmáticas: a contada em prosa por Graciliano Ramos em Vidas Secas; a contada em versos por João Cabral de Melo Neto em Morte e Vida Severina. Esta última constitui-se no objeto de análise do presente estudo, cujas considerações apresentamos a seguir.

João Cabral escreve Morte e Vida Severina sob a forma de um Auto de Natal Pernambucano. A temática do Nordeste de caráter documentário é apreendida pelo poeta e transformada em informação estética no modo como trabalha o signo 
linguístico, tecendo no espaço da escritura verbal os espaços real e poético. Dezoito sequências-quadro, justapostas, montam a representação cênica na linguagem. A escritura poética, mais do que propor uma forma de encenação desse universo, constrói a encenação que se manifesta na textualidade da própria linguagem. 0 objetivo norteador das considerações apresentadas é destacar os recursos estéticos que sugerem a encenação da retirada construída no espaço poético da escritura. Para isso, ressaltamos, no primeiro momento da análise, os traços constitutivos da poética da retirada em Morte e Vida Severina, para, em seguida, apresentar como a encenação é representada no (dis)curso de uma retirada.

\section{A poética da retirada em Morte e Vida Severina}

Na sequência primeira do Auto, a personagem se apresenta. Nesse discurso, quanto mais se define, menos se individualiza (cf. SECCHIN, 1985, p.107). Como há muitos Severinos, os traços que enumera dizem pouco; compõem um perfil criado a partir de fragmentos que, por serem comuns, englobam os caracteres de outros tantos Severinos, iguais em tudo e na vida. A igualdade traça uma identidade única, todos são Severinos e partilham o mesmo universo de privações. Nesse universo, a vida, a morte e a sina explicam a condição severina.

A existência breve e o trabalho estéril reduzem o homem à sua condição mais mínima; tanto a realidade, construída textualmente, como a linguagem revelam a dissolução gradativa do homem e da personagem no "anonimato coletivo" (cf. SECCHIN, 1985, p.107). 0 monólogo de apresentação espelha essa transformação, a linguagem para frisar a impossibilidade da diferenciação na igualdade, torna-se redundante: são as repetições de palavras, a retomada dos versos, a forma como a personagem se interroga e responde, a regularidade rítmica e sonora, tudo sugere uma fala que, por ser redundante, fragmenta a unidade de seu discurso. No entanto, é essa linguagem que reforça a informação semântica - como há muitos Severinos, todos são iguais - e coloca a personagem como representação de um paradigma. Como representação, Severino transforma-se numa personagem-signo, um severino-signo-interpretante de uma condição, inscrito no (dis)curso de uma retirada: 
- Mas, para que me conheçam

melhor Vossas Senhorias

e melhor possam seguir

a história de minha vida,

passo a ser o Severino

que em vossa presença emigra. (MELO NETO, 1975, p.204).

Por ser um representante, a sua retirada é simbólica, pois não é apenas o percurso de um trajeto que ele realiza; é o percurso da existência severina, a caminhada morte-vida, o trajeto percorrido. Severino, como um e muitos, passa, então, a ser caracterizado como um representante dos homens que a seca e o latifúndio escorraçam da terra e, por extensão, da própria vida. A sua história é uma re-escritura da história de todos - a epopeia de uma existência negada: é a vida de "coisas poucas" que traz as marcas da carência e de um trágico destino.

Nessa existência, se a vida é a 'mais mínima', a linguagem que (re)conta essa história é também a mais mínima: os versos são de redondilha e a forma do texto é um auto de natal de tradição pastoril. Esses recursos, que situam a escritura verbal entre a poesia e o teatro, evidenciam a performance estrutural de Morte e Vida Severina: a cena em versos.

Ao todo são 1233 versos distribuídos nas dezoito sequências do Auto; cada sequência contém um número irregular de versos e estrofes. A caracterização da estrofe é dependente do perfil da cena, ou seja, quando a cena constitui-se em monólogo a estrofe é única, nas cenas dialogadas é a predominância da quadra que informa o tipo de estrofe; outro aspecto refere-se à construção dos versos, cujo procedimento revela o efeito pretendido com a composição poética: recriar, na linguagem, o universo severino que o discurso da personagem-retirante atualiza em cena.

Para recriar esse efeito dois são os procedimentos: a predominância da redondilha e da rima pobre. 0 uso do verso de redondilha evidencia que o rigor no trabalho de construção dos versos e os princípios de estruturação da forma poética são guiados pelas leis métricas da carência e do desfalque; sobre a rima, que se caracteriza entre pobre e toante, é devido a uma presença quase que constante da mesma figura fônica. Os demais expedientes, a aliteração, o paralelismo, o refrão, auxiliam na composição da melodia da linguagem; uma melodia 'pobre', pois os recursos (redundantes tanto em nível semântico quanto estrutural) revelam também essa 
pobreza. Nesse sentido, reforçam o efeito poético pretendido enfatizando que a 'pobreza da linguagem' é uma qualidade do signo poético. A linguagem poética busca uma forma de representação comprometida com a informação semântica que veicula; daí não ser apenas a representação da 'morte e da vida severina', mas uma representação da linguagem (que também é) severina.

Nesse sentido, a escritura verbal apresenta uma menor elaboração formal, ou, no dizer de Augusto de Campos (1978, p. 50), êxito comunicativo, diminuição da tensão poética. Este aspecto, se, por um lado, explica a popularidade da obra, por outro, informa o modus operandi de João Cabral: despojar de artifícios a linguagem que conta uma realidade construída a "palo seco". Tal aspecto é determinante na análise da construção poética da retirada, no sentido de que Morte e Vida Severina, ao se colocar como interpretante do universo severino, explicita entre ambos uma relação de analogia. Não é nosso propósito apontar as semelhanças entre a obra e o real, uma vez que o que nos interessa destacar é a retirada construída no espaço poético do texto. Se o direcionamento para o real é um traço constitutivo da obra de João Cabral, o que faz com que a realidade possa ser espelhada no texto, isto não nos impede de dizer que essa impressão de realidade é mediatizada por procedimentos do fazer estético que

\footnotetext{
se manifesta em termos de uma singular imitação: aprendendo com os objetos, coisas, situações, pessoas, paisagens etc., a sua linguagem foi, aos poucos, montando uma nova forma de ver - que o leitor, por sua vez, aprende ao apreendê-la -, jamais permitindo-se a facilidade de um dizer didático, desde que sempre dependente do fazer poético (BARBOSA, 1986, p.108).
}

Acresce a esse aspecto que a organização da obra é dissemelhante à organização da realidade; enquanto esta é regida pelas leis político-econômico-sociais, aquela é regida pelas leis da seleção e combinação, cuja finalidade é pôr em evidência a função poético-metalinguística da linguagem, pois conforme Barbosa "é possível falar numa poesia eminentemente metalinguística: não uma poesia sobre poesia, mas uma poesia que empresta a linguagem de seus objetos para com ela construir o poema" (1986, p.108). É lendo Morte e Vida Severina por esse prisma que podemos extrair o traço singular da poética construtiva de João Cabral, que não reside apenas na sua leitura do real, mas no modo como através dessa leitura a narrativa do real foi-se enredando na própria linguagem. 
A narrativa do real - o drama do homem nordestino num meio físico e social hostil - é recontada por João Cabral e convertida em informação estética. Nesse processo, a intenção crítico-criativa do poeta é manifesta na construção verbal, uma vez que o propósito do texto não é simplesmente retratar a realidade nordestina, mas sim de reduzi-la à linguagem, ou seja, podemos dizer que, em Morte e Vida Severina, o universo sígnico é análogo ao universo real. Esta relação é construída a partir da característica dominante que a história do retirante revela: a pobreza (do homem e da terra) que a composição poética incorpora e dimensiona.

As 'coisas poucas', feitas de uma 'soma de não', características do universo severino, tomam as formas de uma linguagem construída de poucas coisas para justificar a correspondência entre a ausência de idealização da realidade e a ausência de idealização da linguagem. É a linguagem (poética) severina que traduz a natureza real e revela a natureza da escritura verbal que incorpora à linguagem do poema a oralidade do discurso: as redundâncias, os rodeios de linguagem, o vocabulário prosaico e a linearidade. Dada essa característica da composição poética, a cena em poesia incorpora os matizes da oralidade de modo singular, oral sobre fundo poético, quasecanto, quase-reza, quase-verso.

A pontuação gráfica reconstitui a pontuação da fala oral, traduz na fala em versos, que ora é um monólogo, ora um diálogo, as pausas da oralidade. A sintaxe lógico-discursiva desse discurso evidencia o caráter narrativo próprio do discurso oral, no verso linear, matriz da construção narrativa, que faz do verso um quase-verso, prosa em poesia, no sentido empregado por Haroldo de Campos: "não prosa poética nem poema em prosa, mas poesia que fica ao lado da prosa pela importância primordial que confere à informação semântica." (1992, p.83). A prosa em poesia é resultante: das modulações interrogativo-exclamativas nos monólogos, da simplicidade de linguagem, do estilo direto dos discursos, da repetição, do paralelismo.

No discurso oral, as repetições reafirmam as relações sinonímicas; na linguagem poética, as repetições são marcas da organização estrutural; uma vez que portadoras de informação, cujo efeito é acentuar, gradativamente, a dimensão da carga semântica do signo. 0 quase-verso vai sendo tecido por fios-recursos do padrão oral; fios invisíveis, pois põem à mostra a dimensão poética do signo verbal. A forma poética se faz ladainha, oração e lamento: apoiada no ritmo lento da cena, nas rimas, na repetição, no 
refrão que tal como na Oração se faz súplica e lamento, que, com pequenas alterações, configura a ladainha na linguagem e transforma o verso em quase-reza. A esse aspecto acresce a questão do ritmo-binário que sugere a ideia de movimento, cuja regularidade marca o (com)passo da retirada: o retirante caminha de verso em verso, de sequência em sequência ao cumprir a sua ladainha, o percurso morte-vida, do sertão nordestino para a cidade de Recife.

\section{A retirada e a comemoração da natividade}

0 percurso da viagem principia com a vida em retirada representada no enterro em rede (na segunda sequência: "Encontra dois homens carregando um defunto numa rede, aos gritos de: Ó irmãos! Irmãos das almas! Não fui eu que matei não!" (MELLO NETO, 1975, p.205)). 0 diálogo entre Severino e os "irmãos das almas" enfatiza a força da "morte matada" (ibdem, p.206) através da seleção lexical que aponta para uma desfiguração do referente - o cortejo fúnebre - para em seguida recriá-lo enquanto figura que traduz a imagem da vida em retirada. Na paisagem de morte, onde a "terra não dá nem planta brava" (ibdem, p.205), e há sempre uma "bala voando desocupada" (ibdem, p206); a retirada do homem é uma metáfora da retirada da vida.

À realidade do êxodo rural se superpõe a realidade do contexto poético: a viagem é, então, comparada a uma ladainha, oração-enredo que pontua a via-sacraseverina. As vilas e cidades formam um rosário que a linha do rio enfia e que o retirante vai "saltando de conta em conta, passando de vila em vila" (ibdem, p.209), até chegar ao "Recife, derradeira ave-maria"(ibdem, p.223) Severino, como um signo-interpretante, reconstitui, em sua caminhada, o roteiro da sina Severina - a submissão às forças sociais e ao meio físico, a fuga da morte prematura e a luta pela vida a retalho. Nesse trajeto, é o fio-da-vida, o fio condutor de sua história-viagem, que ele vai desenredando.

Severino caminha da morte (do sertão) para a vida (na cidade), uma caminhada às avessas, uma vez que morte e vida constituem-se nos polos de seu trajeto, uma representação metafórica do trajeto real de seu percurso. A inversão da ordem natural do sintagma vida e morte e a sua qualificação severina montam uma equivalência entre 
os termos do percurso, cuja finalidade é resgatar a qualidade da vida no universo severino, uma vida que a morte norteia:

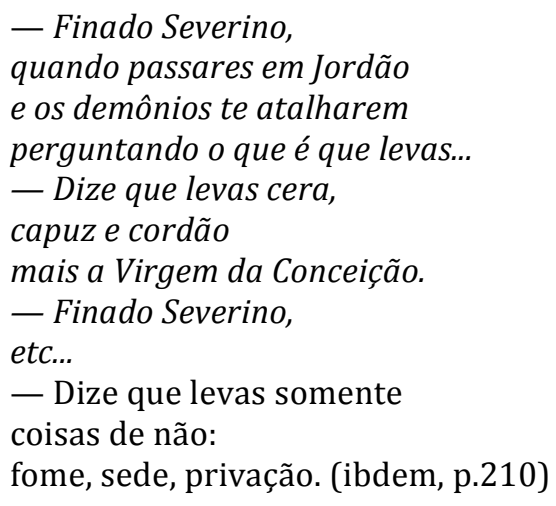

A reza traduz o ritual da morte, a paródia denuncia a vida; o texto paródico subverte o sentido religioso da oração - uma soma de "coisas de não" é o que o homem leva, uma vez que "a paródia dos homens às rezadeiras é paródia às palavras que fundem esperança esquecendo o que não deveriam esquecer [...] é uma paródia à reza dentro da história, é uma paródia à lírica dentro da linguagem" (LIMA, 1995, p. 269). Como um contraponto à reza, a paródia estabelece uma dupla dissonância: 1) entre o canto e as condições de vida, a lamentação fúnebre é um artifício que mascara a existência severina: dissimular com a vida pouca as muitas exigências da morte; 2) entre os cantadores, sugere pela disposição dos versos, a manifestação de vozes discordantes que, através da paródia, apresentam o avesso da vida. A fórmula da reza é preenchida com o texto paródico e provoca o deslocamento semântico do texto matriz que é realçado. A intercalação reza/paródia ultrapassa a disposição linear dos versos, revela a sobreposição de vozes, desautomatiza o verbal e cria uma relação fundo/figura: como fundo a reza, como figura a paródia. 0 estranhamento dessa relação gera um efeito de distanciamento, a crítica é construída na montagem intertextual, o texto paródico põe em relevo a carga informativa do signo.

$\mathrm{Na}$ caminhada do retirante, a paisagem social e humana se fundem e criam um terceiro elemento, a paisagem morte/vida que define o roteiro da viagem. A monotonia da mesma paisagem é enfatizada na monotonia da linguagem: é a mesma figura fônica que percorre todo o texto (principalmente, nos monólogos do retirante), são as rimas, as repetições de palavras e a construção anafórica dos versos que criam um desenho 
rítmico do verso, uma figura sonora que vai tecendo na linguagem a ladainha do discurso-reza, um lamento na linguagem, cujo efeito é realçar o lamento da situação.

A dimensão dessa situação é flagrada no encontro de Severino com a carpideira, é o diálogo entre a vida e a morte que a cena constrói. A procura de trabalho - metáfora da proposta de vida - vai sendo gradativamente desgastada na fala da carpideira. 0 trabalho rural se transforma no ritual da morte: "só os roçados da morte/compensam aqui cultivar,/e cultivá-los é fácil:/simples questão de plantar; [...] pela colheita: recebese/na hora mesma de semear." (MELLO NETO, op. cit. p.216-217); isso porque viver da morte é a atividade produtiva da região. A comparação metafórica é criada a partir do paralelo estabelecido entre a morte e a vida que, através da inversão da ação (cultivar os roçados da morte) ou da causa mortis (as estiagens e as pragas), opera a metamorfose da produção de vida (a lavoura) em produção de morte. O que é negativo, porque dizima o homem, passa a positivo porque qualifica o trabalho "recebe-se na hora mesma de semear" (ibdem, p.217). A imagem da morte que o signo metafórico cria parte, assim, do universo contíguo ao homem, a lavoura, que explicita a relação de dependência do homem em relação à terra.

Esta relação de dependência é enfatizada durante todo o percurso da caminhada; de certa forma, a referência geográfica, além de contextualizar os episódios, transforma-se no cenário da encenação verbal. Nas primeiras sequências do Auto, a paisagem denuncia a morte: é a caatinga, o agreste, o sertão, onde a seca é o traço comum à paisagem e à vida. Quando a viagem se aproxima do litoral, a paisagem de "pedra e areia lavada" (ibdem, p.206) é substituída pela "terra doce, branda e macia" (ibdem, p.217). 0 impacto da mudança da paisagem se faz sentir pelo signo metafórico, que tem como referente o canavial que tudo domina. No entanto, a paisagem contrasta com a vida: se a paisagem convida o homem a ficar, a estrutura latifundiária se transforma, agora, no agente que expulsa o homem da terra e da vida. 0 latifúndio espelha a tensão do homem num mundo de tensões: trabalhador eterno numa terra de outro. 0 signo poético resgata esta situação nas analogias estabelecidas entre o homem e o mundo rural. Na cena do enterro do lavrador, com a morte o corpo se transforma em semente, adubo e colheita; com a morte a terra é dividida, e do latifúndio o lavrador recebe a "conta menor" (ibdem, p.218). 
Para a caracterização da cova convergem as qualidades do pedaço de terra que o lavrador não teve em vida e que com o trabalho realizado - a morte - consegue ter a terra dividida. A ironia desta situação é construída a partir das qualidades da cova. A "conta menor" que, na relação "não é cova grande" porque "medida", contrasta com a "cova grande" para o "pouco defunto" e revela a situação real: "mas a terra dada/não se abre a boca" (ibdem, p.219). Nesse contexto, a morte surge não como um fim, mas como ganho de uma causa: a parte do latifúndio, ainda que "grande" para a "carne pouca" (ibdem, p. 219), representa a "roça" e, mais do que isto, é "como roupa feita à medida" (ibdem, p.220). A tríade roça-roupa-cova transforma o lavrador em senhor da terra.

$\mathrm{O}$ signo metafórico acentua a dependência do homem à estrutura latifundiária, a força da repetição qualifica a ação: tanto na vida quanto na morte a finalidade do homem é "trabalhar a terra" (cf. SECCHIN, 1985, p.111). A repetição gera a redundância, semântica e estrutural, cujo efeito revela a essência cruel do sistema latifundiário que despoja o homem do próprio homem. A metáfora - síntese dessa relação - se faz representar por aquilo que resta e representa o 'lavrador': "uma seca semente" (ibdem, p.221). Esta imagem, no decorrer da cena, produto da opressão do meio físico e social, explode na imagem da "vida que deu sem soca"(ibdem, p.221), porque feita de coisas poucas. A qualificação metafórica (maniva, rebolo, grão) se desdobra em outras metáforas (espiga debulhada, espiga no sabugo, maçaroca banguela), revelando que o enterro é a hora da plantação. 0 gesto de enterrar o morto equivale ao plantio do corpo: "semear ao comprido" (ibdem, p.220), "semear na coveta", "semear no leirão" (ibdem, p.221). A gradação das imagens que reduzem o corpo sem força (vida) ao grão traduz o que subsiste à miséria e à exploração. A imagem de despojamento do homem referencializa a existência negada; a analogia entre enterrar e plantar traduz a qualidade dessa existência: o corpo é nada, é como a espiga debulhada. No entanto, isto é tudo que sobrou do homem, "coisa vasqueira", "coisa pouca", é a vida “que deu sem soca" (ibdem, p. 221).

Durante a caminhada, a morte é o que define a condição da existência severina, caracteriza o mundo de 'coisas poucas' que o retirante vai encontrando a cada etapa do percurso. Nesse trajeto de coisas poucas, a esperança do retirante em encontrar uma situação diferente vai sendo reduzida, pois percebe que entre a vida e a morte a "diferença é a mais mínima" (ibdem, p.222). Ao chegar à cidade, a força da morte se 
intensifica na conversa dos coveiros, a morte geral e anônima do sertão contracena com a morte protocolada da cidade. É a hierarquia das mortes, fazendo da morte em cemitério uma maneira de marcar a diferenciação social em vida.

$\mathrm{Na}$ ironia da fala dos coveiros, na descrição dos tipos de morte, que estão alocadas em bairros, incita o humor e revela o anti-riso, um riso crítico que desmascara as contradições do mundo severino: para o enterro de rico, confluem todas as imagens que conotam ostentação, luxo, riqueza, são as metonímias de base metafórica, pompa, protocolo, cenografia, que descrevem a morte de poucos: "no máximo um transatlântico/chega ali cada dia" (ibdem, p. 224); para o enterro de pobre, confluem as imagens de multidão, estação de trem, estação de ônibus, e anonimato "são os que jamais usam luto/e se enterram sem salvo-conduto" (ibdem, p. 227).

O signo metafórico revela o efeito criado, expõe a uniformidade do processo de composição da cena: na descrição exaustiva do signo metafórico, que passa a representar o nada, "morre gente que nem vivia" (ibdem, p. 228), desgasta-o, para em seguida revesti-lo de concretude:

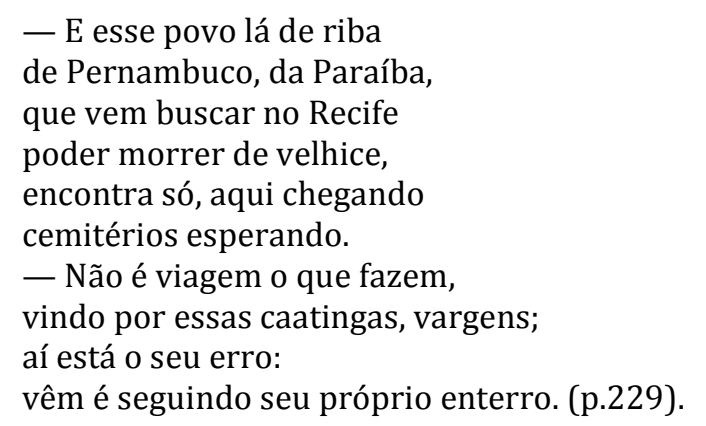

A via-sacra-severina termina quando o retirante chega à cidade e encontra ao término de seu percurso só "cemitérios esperando" (ibdem, p.229). Percebe, então, que o tão esperado "aluguel com a vida" (ibdem, p.229), força propulsora de sua caminhada, se rarefaz ao descobrir o significado de sua própria caminhada. A descoberta dessa situação marca o clímax de seu percurso: apressar a morte e cumprir o trajeto de seu destino; pois a vida na cidade é também severina. Nesse momento do Auto, o discurso do retirante marca-se por um sentimento de renúncia e desespero que se intensifica no diálogo que mantém com Mestre Carpina.

Ao discurso de negação da vida que passa a caracterizar a fala de Severino, se contrapõe o discurso de afirmação da vida de Mestre Carpina. É a vida e a morte que dialogam, uma variação do diálogo de Severino com a carpideira. A cena é construída 
entre perguntas e respostas que vão, gradativamente, compondo a imagem da miséria que caracteriza a vida no mangue. 0 estilo simples e direto dos discursos, a retomada e a ampliação, ora da pergunta ora da resposta, nos permite identificar no procedimento construtivo da cena, os procedimentos oriundos da poesia popular. No entanto, não é este o aspecto central que define o seu modo de construção, pois o que interessa ressaltar é como o procedimento adotado contribui para a construção da imagem da miséria.

A seleção lexical que constrói tal imagem e estabelece a relação entre o termo real, a miséria, e o termo figurado, "rios sem água", "grandes braços de mar", "mar largo" e "oceano vazio" (ibdem, p.231-232), é determinada pelo próprio contexto, o mangue. A miséria, antes de ser relatada, é intensificada na gradação das metáforas; apresenta-se como uma imagem verbal em que o signo, mais do que representar, presentifica. É a qualidade da miséria que o signo traduz: a miséria como um "oceano vazio" (ibdem, p.232) "alaga e devasta a terra inteira" (ibdem, p.231). 0 diálogo de Severino com Mestre Carpina é uma forma de retomar os dois termos do percurso da caminhada e explicitar a equivalência entre a morte e a vida. Neste cenário de miséria, a desistência da vida, representada pela vontade de Severino "de saltar fora da ponte e da vida" (ibdem, p.233), é rebatida com o nascimento da criança que salta para dentro da vida. A anunciação é um momento singular da escritura do Auto de Natal Pernambucano:

\footnotetext{
A comemoração do nascimento da criança, revela o Auto dentro do Auto que retoma os tradicionais quadros e personagens do pastoril, podendo se estabelecer quase que de cena a cena, os traços analógicos desse parentesco formal, que as mudanças de figuras e situações apenas conseguem disfarçar: uma mulher do povo substitui o Anjo da Anunciação, os vizinhos, com seus elogios tomam o lugar dos anjos que adoram e guardam o menino, e, com seus presentes, os reis magos; o mocambo é o presépio do Menino Deus, e seu José, São José. (NUNES, 1971, p.86).
}

A anunciação do nascimento é a anunciação da própria vida. A comemoração tem como palco o cenário do mangue; em função do espetáculo da vida, o ambiente se transforma:

\footnotetext{
— Todo o céu e a terra

lhe cantam louvor.

Foi por ele que a maré

Esta noite não baixou.

[...]

— E este rio de água cega,
} 
ou baça, de comer terra, que jamais espelha o céu, hoje enfeitou-se de estrelas. (MELLO NETO, 1975, p.233-234).

A vida, agora, contamina a paisagem: no encharcado lamaçal a transformação metafórica do mangue sugere a luminosidade do ambiente. 0 momento epifânico é traduzido na reiteração da pobreza (dos presentes e da linguagem). Os presentes se diversificam (caranguejos, papel de jornal, água de Olinda, canário da terra etc.), no entanto, o procedimento construtivo da cena, a estrutura paralelística e a repetição de versos, revela a variação da mesma imagem; os presentes trazem as marcas da vida (e da linguagem) severina.

O gesto solidário traduz as condições de sobrevivência no mangue, e é a luta pela sobrevivência que os presságios das ciganas vêm reforçar. As predições não se excluem, antes explicam o destino possível: quer na predição voltada para o mangue ("vestido negro de lama/voltar de pescar siris/[...] fazendo dos dedos iscas/para pescar camarão." (ibdem, p. 237), quer na voltada para a industrialização ("vejo-o dentro de uma fábrica:/se está negro não é lama,/é graxa de sua máquina," (ibdem, 238), a ênfase é situar a vida severina; a ironia realça o tom de tragédia de ambas as falas.

A essa vida sem perspectivas se opõe a vida com sua presença viva, espelhada na criança pálida e franzina que traz as marcas de "humana oficina" (ibdem, p.239). E, novamente, o gesto solidário contempla a força da vida em meio à miséria: "belo porque com o novo todo o velho contagia./Belo porque corrompe/com sangue novo a anemia./Infecciona a miséria/com vida nova e sadia." (ibdem, p. 240 ).

A beleza da criança é comparada a tudo que indicia vida, uma beleza metafórica, construída a partir de metonímias do mundo severino, que ora se referem à natureza (o coqueiro, o avelós, a palmatória, a soca, o mar), ora se referem àquilo que se opõe à força opressiva desse mundo, o 'sim' da vida com a soma de "coisas de não" (ibdem, p.210) da existência severina. 0 refrão rítmico e melódico contagia a linguagem, sugere o canto de louvor e triunfo à vida, e à beleza do recém-nascido. 0 quase-canto é sugerido pela textura sonora, agora, tecida por fios frágeis, pois que é o fio da vida severina que se desenrola. A criança "pálida e franzina" (ibdem, p.239) representa a vitória da vida, ainda que feita de uma soma de coisas poucas; é a vida que salta e contrasta com a pobreza do mangue. É a qualidade do novo que dimensiona a vida, "a fábrica que ela mesma, teimosamente, se fabrica" (ibdem, p.241). 
Com o espetáculo do nascimento o fio-da-vida, que o retirante vinha desenredando desde o sertão, tem, então, sua decodificação na encenação da vida: é ver a vida desfiar seu fio, metáfora do fio condutor do espetáculo linguístico que reata os dois momentos da encenação - a morte e a vida severina.

\section{A encenação representada no (dis)curso de uma retirada}

Quase todo e qualquer espaço é palco. Cyro Del Nero

Copeau define encenação como "o desenho de uma ação dramática" (apud PAVIS, 1999, p.123). Ação que se desenvolve num determinado espaço e com certa duração; o texto, o ator e o público completam os elementos necessários para a concretização desse desenho. Uma "linguagem no espaço e em movimento" (ARTAUD, 1985, p.61) caracteriza o dispositivo que define a natureza dessa prática de linguagem; a relação palco-plateia estabelece a especificidade da representação teatral. Na escritura em cena, é importante destacar a função da cenografia uma vez que o desenvolvimento da ação será representado em um palco. Para Serroni, a cenografia "é a dramatização do espaço, sempre complementada pela atuação" (2013, p.25).

A encenação em Morte e Vida Severina realiza-se textualmente, é dependente, portanto, de uma solução imaginária para que possamos compreender que essa modalidade de encenação prescindiu de vários dos elementos caraterísticos da linguagem cênica. 0 dispositivo que rege a 'montagem do espetáculo' é linguístico; o desenho da ação dramática está configurado segundo os padrões da discursividade da escritura textual. No entanto, vale ressaltar a especificidade dessa escritura: metafórica e poética, cria imageticamente uma possível encenação.

João Cabral escreve Morte e Vida Severina sob a forma de um Auto de Natal Pernambucano; nessa forma de composição temos dois aspectos predominantes: a criação textual escrita em versos e destinada à representação cênica e a apropriação de elementos do universo severino. Essa constituição ambivalente da cena verbal é 
decorrente de uma prática intertextual: são os paradigmas do teatro narrativo ${ }^{1}$, forma de representação característica dos mistérios e moralidades que são reoperacionalizados; assim como é o aspecto regional do Nordeste que a forma poética incorporou no discurso das personagens; discurso que retoma as formas comuns do cancioneiro popular nordestino. Em relação aos mistérios e moralidades, o traço comum a essas formas de representação refere-se aos paradigmas que montam o sintagma estrutural de tais formas, como, por exemplo, o desfile de personagens, a representação de caráter popular, a variedade e a autonomia das cenas representadas, a divisão do texto em jornadas, a sequência linear da ação e a presença de uma temática de caráter moral e/ou religioso como suporte da ação dramática.

Em Morte e Vida Severina, tais expedientes foram quase totalmente utilizados; o que difere é o motivo desencadeador da ação dramática que está centrado numa temática de caráter social deflagrada por meio da construção poética. Os demais expedientes utilizados na criação das sequências-cenas caracterizam o Auto de Natal Pernambucano como um interpretante da cena medieval, uma vez que o teatro desse tempo apresenta uma forte tendência popular, que diz respeito não apenas à forma de representação e à encenação do espetáculo, como também ao próprio espetáculo que era encenado por e para o povo.

Além da retomada dos paradigmas do teatro narrativo, podemos estabelecer vínculos com o teatro de Gil Vicente, cuja proposta estética "tanto na escolha dos temas como nos processos teatrais e nas formas versificatórias, manteve-se fiel à sua vocação popular" (SPINA, 1983, p.19). Spina ressalta que "o seu teatro não pode ser jamais

\footnotetext{
${ }^{1}$ Forma de encenação-representação que remonta à tradição herdada da Idade Média, principalmente, daquela herdada da Península Ibérica, a encenação de temas religiosos. As origens desse teatro, segundo José Saraiva, estão alicerçadas na necessidade de dar expressão e forma didática à doutrina da Igreja. De acordo com Saraiva, o teatro desse tempo integra-se no conjunto dos ofícios divinos e do ano religioso, ilustrando-o. 0 ano religioso é, como a catedral, uma enciclopédia. Ao longo dele toda a história do mundo, constituída pelo antes e depois de Cristo e pelas vidas dos santos, assim como as quatro estações da Natureza, têm o seu lugar competente. Como o ano religioso, o teatro medieval parte-se em dois grandes ciclos: a Natividade e a Paixão. Dentre as formas de representação desse tipo de teatro, os mistérios são os que mais se aproximam. Os mistérios consistiam na encenação de narrativas bíblicas; a cada cena representada correspondia uma parte da Bíblia, não havia, assim, uma preocupação em centralizar toda a encenação em torno de um episódio nodal, isto em consequência do caráter exclusivamente narrativo da representação cênica. Essas representações, que chegavam a durar vários dias, tinham como objetivo contar toda a História Sagrada, desde o seu início até o Juízo Final. Daí o caráter de autonomia das cenas, o desfile linear de episódios que justapostos montavam o sintagma narrativo, que era, assim, composto por uma série de dramas menores ao redor do drama central da Natividade e/ou da Paixão. (José Antônio Saraiva. Gil Vicente e o fim do Teatro Medieval, 1985).
} 
entendido se analisado e concebido segundo os padrões de uma estética que não seja a estética do teatro popular"(ibdem, p.19). Completa dizendo que "o teatro vicentino veio quebrar a estética dos olhos e do ouvido, para impor uma estética da reflexão" (ibdem, p.21). Traço esse presente em Morte e Vida Severina no sentido de que sugere a questão ideológica no texto encenado: é a temática social, a morte e a vida severina, contrastando com a temática de fundo religioso comuns aos mistérios e ao auto de natal de tradição pastoril.

O desenho da ação dramática em Morte e Vida Severina, construído discursivamente, está indiciado na primeira sequência: “O retirante explica ao leitor quem é e a que vai" (MELLO NETO, op. cit. p.203). A sequência se transforma em cena. Nesta cena, temos a recuperação da tríade essencial para que a encenação se realize: texto, ator e público. 0 texto a ser encenado é a história da morte e da vida severina, o ator é Severino, o espectador (virtual) é o leitor. Com essa configuração é estabelecida a relação palco-plateia; os demais elementos da linguagem teatral, a temporalidade e o cenário, foram sugeridos na encenação/relato da retirada.

O cenário, que é a dramatização do espaço, foi montado num palco móvel, recupera do dispositivo teatral a ideia de uma "linguagem no espaço e em movimento" (cf. ARTAUD, 1985, p.61) no trajeto do retirante do sertão à cidade do Recife. Nessa modalidade de encenação, a caracterização do espaço-tempo da cena é metafórica, uma vez que é o meio físico e social hostil que contextualiza o cenário (paisagem) da encenação (viagem), tanto no palco da caatinga como no palco do mangue. 0 'princípio cenográfico’ para qualificar tais cenários é sugerido verbalmente por meio dos signos que conotam morte. Os 'elementos cênicos' que qualificam tais cenários está na descrição dos ambientes (paisagem) que, imaginariamente, são 'arranjados' para compor o espaço dramático da cena. A partir da anunciação, o cenário 'montado no palco do mangue' transforma-se, "o encharcado lamaçal" (MELLO NETO, op. cit. p.234) passa, através da inversão, a conotar vida. Na transformação metafórica do ambiente, ocorre a suspensão do tempo que contrasta com a temporalidade da viagem, onde o tempo é caracterizado como o tempo de "desgaste dos seres e das coisas", um "tempo destrutivo, uma temporalidade invertida e roubada." (cf. NUNES, 1971, p.86).

A montagem do espetáculo - um ato em dezoito sequências-cenas - é realizada a partir dos títulos que precedem cada uma das sequências. Título-signo de caráter 
indicial que situa o espectador e roteiriza os procedimentos da encenação. Tal característica advém dos seguintes aspectos: os títulos sugerem a continuidade da ação narrativa, indiciam a passagem temporal decorrente da passagem pelos diferentes locais. Os títulos referencializam a fala de um narrador que faz do relato da cena um meio de reatar o fio condutor da encenação discursiva. Cada título representa, assim, uma sinopse da cena. À maneira de uma marcação cênica, pontua o desempenho dos atores no espaço cênico da linguagem: a presença constante da personagem-Severino que realiza uma viagem e assiste a diferentes episódios; nos episódios contracena com a variedade de personagens, cuja atuação é determinada pela duração da cena.

Cada personagem tem, portanto, uma atuação momentânea, existe no espaçotempo de cada cena. Sem nome, as personagens são caracterizadas pela ação que as qualifica: são os carregadores de rede, os cantadores de excelências, a carpideira, os coveiros, os amigos do morto, as ciganas, os vizinhos; anônimos personagens que constroem no dia a dia o texto teatral do espetáculo verbal. A inexistência de uma intriga paradigmatiza o perfil das personagens, uma vez que a própria existência da personagem está condicionada ao espaço caracterizador da cena. A duração da cena permite diferenciar a personagem-retirante das demais personagens e, também, permite identificar o seu perfil, uma vez que a montagem da encenação revela que o espetáculo não é apenas dirigido ao leitor, pois que a encenação tem como espectador primeiro o próprio retirante. Esse aspecto é confirmado no título da última sequência: “O carpina fala com o retirante que esteve de fora, sem tomar parte em nada" (MELLO NETO, op. cit. p.241).

Severino é, então, caracterizado como ponto de convergência da ação dramática, uma vez que se estabelece uma relação dialógica entre o que Severino representa e a sua própria representação, isto é, a sua atuação como ator (personagem). Severino realiza uma viagem, índices-sígnicos presentes nos títulos das sequências sugeriram a caminhada, ação que num primeiro momento poderia aproximar a personagem do modelo que ela representa, o nordestino. No entanto, o caráter de personagem é dado não pela viagem, propriamente, mas indiciado nos monólogos, os quais revelam uma não-ação, ou seja, é através dos monólogos que se manifesta uma ação interior, os momentos de reflexão, que distanciam a personagem do modelo que ela representa, uma vez que 
Severino é personagem nutrida pela experiência e pela observação da vida e construída a partida de um modelo real - o nordestino - mas a intenção de autoconhecimento e autocrítica, que o poeta lhe atribui, transforma-o em personagem profundamente delineada nas camadas subjacentes do espirito, mas distante da região e do panorama social do Nordeste. Sua singularidade não decorre da ação que a manifesta, já que esta é reduzida dramaticamente, mas do enfoque onisciente com que a revela o lirismo do autor e que preside o maior nível de comunicação com o poema. (FERRARA, 1978, p.17).

Severino, caracterizado como um espectador, distancia-se dos acontecimentos encenados - condição primeira para que a crítica de fato se estabeleça - e revela, assim, a definição de um perfil interior. 0 deslocamento de sua ação vai-se efetivando no espaço-tempo da encenação onde o seu perfil interior é construído e onde, também, se justifica o caráter de uma não-ação, pois o que ele realiza é a qualidade de uma ação: 'retira-se' para contar a sua história. Em sua narrativa faz avançar a ação dramática, sua narrativa representa a vida, a ausência da narrativa representa a morte; por isso que até a chegada ao Recife cada cena presenciada é a representação de um episódio isolado, paradigmas de atuação que são insuficientes para construir a trama ou dinamizar a intriga. No entanto, são suficientes para representar textualmente a encenação.

A partir da anunciação do nascimento, que é uma metáfora da anunciação da vida, cessa a narrativa do retirante, ele não é mais 'convidado' a participar do espetáculo, apenas assiste, pois a sua narrativa é, então, substituída pela própria vida que assume, agora, o contar e revela o eixo central do enredo: o conflito morte/vida. Este aspecto revela um fazer textual que desenreda a trama entretecida na rede sígnica, malha textual que expõe o texto como linguagem, ou seja, que "é o próprio texto feito personagem e sujeito de um jogo textual criado a partir do entrechoque de atorestextos" (SEGOLIN, 1978, p.80). Este aspecto explica por que Severino e as demais personagens não se caracterizam, propriamente, por uma ação efetivamente realizada, mas por uma ação em potencial; uma ação virtual que mascara e revela a atuação dos atores (personagens) desenhada na textualidade da escritura: é a morte e a vida que, num plano alegórico, dialogam o que constitui o verdadeiro universo da encenação discursiva.

Os títulos revelam ainda: a independência dos episódios encenados (velórios, enterramentos, nascimentos) e o seu caráter popular na inclusão dos elementos culturais do universo nordestino: as excelências, a carpideira e a retomada do auto 
pastoril. A disposição desses episódios na montagem do espetáculo textual organiza os dois momentos da encenação: a viagem e a comemoração do nascimento da criança, cujas cenas são construídas entre monólogos e diálogos. Essa alternância, no primeiro tempo do espetáculo, determina o perfil da encenação: nas cenas dialogadas são representados os diversos episódios; nos monólogos representam-se os momentos de reflexão do retirante. Os monólogos interrompem a cena, e essa interrupção, através das reflexões, permite estabelecer o diálogo entre uma cena e outra e coloca a personagem-Severino como um mediador da cena. No segundo tempo do espetáculo, na encenação do "Auto dentro do Auto", repete-se a alternância; o espetáculo termina com a fala de Mestre Carpina.

Na construção das falas, os recursos estéticos (as redundâncias, as repetições de versos e de expressões, as metáforas construídas por contiguidade, a restrição léxica própria do discurso severino), por serem reincidentes, tornam a mensagem redundante tanto em nível temático quanto estrutural; portanto, reduzem a densidade poética. Em consequência, geram uma maior comunicação, pois sendo os recursos estéticos repetitivos, não causam estranhamento, uma vez que se integram com naturalidade no código poético do poema e, também, na atuação dos atores na cena verbal.

Na encenação verbal, a descaracterização da referencialidade do signo é um traço constitutivo do texto dramatizado, no sentido de que exerce uma ação desmistificadora da própria encenação: sugere uma montagem paratática das cenas que realça, no percurso contínuo da viagem, o percurso descontínuo da ação dramática. Em cada sequência um quadro; em cada quadro uma cena; em cada cena novos personagens em representação. Personagens que representam falas isoladas, os interpretantes da cena do real, índices - fragmentos que compõem o discurso da personagem em cena.

No desenvolvimento do espetáculo, temos a construção de um discurso feito de várias vozes que contracenam dialogicamente (a alternância entre monólogos e diálogos) e que subvertem a ação dramática, cujo desenho se realiza, portanto, através de um fazer textual e não exclusivamente de um fazer da personagem. Esse procedimento de criação da cena verbal explica o porquê da alternância entre monólogos e diálogos até a chegada ao Recife; explica, também, por que a dramaticidade da ação é enfatizada nos monólogos; pois nas cenas dialogadas, os 
diálogos são paralelos e por isso subvertem a ação dramática, uma vez que apenas indiciam a dramaticidade que é, então, retomada nos monólogos do retirante. É através do diálogo intertextual dos dois tipos de discurso (monólogos e diálogos) que a mise-enscène construída com palavras sugere uma modalidade de encenação em que estão ausentes todos os elementos físicos característicos da encenação teatral. Isto significa perceber, na escrita invisível de Morte e Vida Severina os índices linguísticos que sugerem a encenação virtual. Tais marcas, conforme destacamos, estiveram presentes nos títulos e no modo de construção das sequências-cenas.

A escritura verbal sinaliza para uma possível encenação, mas é um texto incompleto, pois é feito de indicações e brechas, é, portanto, uma mediação para traçar o esboço a partir do qual a dramaturgia foi construída com os recursos imagéticos do verbal. A composição textual cria a ambiguidade entre dizer e mostrar, sugerindo, na visualidade da palavra escrita, a linha norteadora da dramaturgia do espetáculo: a encenação é sinalizada pela palavra escrita, portanto, construída discursivamente.

\section{Considerações finais}

A poética da retirada em Morte e Vida Severina, conforme apontado anteriormente, é contada em versos, os recursos estéticos, ao aumentarem a taxa de redundância da mensagem, informam menos; no entanto, em função da proposta de João Cabral, a redundância enfatiza a carga semântica do signo e, nesse sentido, passa a funcionar como um signo informativo, como um traço estrutural da composição da cena verbal. Do mundo severino, o Auto coloca-se como um interpretante (ao qual já nos referimos), como um texto que revela o real transformado em imagem poética; entre a encenação da morte e da vida é estabelecida uma relação de equivalência, uma vez que ambas são regidas pela condição severina.

Tal condição, porque qualificada de poucas coisas, uniformiza tanto a morte quanto a vida. 0 caráter de uniformidade contamina a linguagem. 0 paralelo é montado metaforicamente. Na primeira parte do Auto, as analogias são estabelecidas entre o homem e o mundo real; e, na segunda, entre o homem e o universo do mangue. Na construção desse paralelo, dois são os artifícios de linguagem utilizados: a ironia e a paródia. A ironia deixa-se revelar pela leitura que é feita do signo em representação - de 
crítica, na cena do enterro do lavrador; de humor, na cena dos coveiros, ou de tragédia, na previsão das ciganas - é uma estratégia que realça as contradições do mundo severino. A paródia reforça a crítica social que permeia a escritura verbal; paródia temática que descaracteriza o mistério e o sobrenatural como agentes do destino do homem, ao imprimir-lhe as marcas da historicidade: no presépio do mangue, as figuras bíblicas são humanizadas e contracenam com a ironia das ciganas que vêm "do Egito" (MELLO NETO, 1975, p236); o momento epifânico é a comemoração da "explosão de uma vida severina" (ibdem, p241). A paródia se manifesta, num sentido mais geral, em relação à própria forma de composição, ou seja, Morte e Vida Severina caracteriza-se como sendo um Auto de Natal, no entanto, no texto que objetiva a vida, a morte é uma 'atividade festiva' e a vida é 'sempre a mais mínima'. Mas a vida supera a morte, e nesse aspecto, o Auto de Natal Pernambucano recupera do auto pastoril o seu sentido positivo: a fábrica da vida que teimosamente se fabrica sugere a vitória (ainda que parcial) da vida.

A retirada e a comemoração da natividade compreendem os dois momentos da encenação. 0 movimento, na primeira parte do Auto, é lento e sugere a ideia de peregrinação da caminhada-ladainha. O lamento da fala compõe um discurso monótono, pois é a ladainha que permeia a peregrinação-discurso da via-sacra severina. 0 tom processional é marcado pelo ritmo lento dos discursos, pela distribuição das sequências e pela regularidade rítmica presentes na construção da encenação verbal. Na segunda parte, a partir do nascimento, a paisagem e a linguagem (ainda que severinas) se transformam; o movimento é mais rápido, as cenas são mais curtas, predominam a quadra e o dístico, é a encenação da comemoração que dá à linguagem o seu ritmo.

A encenação representada no (dis)curso de uma retirada foi construída com palavras que, por meio dos dispositivos discursivos, realizou uma tradução poética dos dispositivos cênicos: num cenário imaginário e virtualmente sinalizado nos títulos das sequências, ambientou uma atuação de atores (personagens), também, imaginária. 0 desenho da dramaturgia da cena é uma construção de linguagem. A justaposição das sequências espacializou o verbal e criou a ilusão de um espaço cênico, condição imprescindível para projetar a encenação do espetáculo verbal construído cenicamente 
na textualidade da linguagem: a atuação da morte e da vida encenada metaforicamente no (dis)curso de uma retirada.

\section{Referências}

ARTAUD, Antonin. O teatro e seu duplo. 2. ed. Trad. de Teixeira Coelho. São Paulo: Max Limonad, 1985.

BANDEIRA, Manuel. Vou-me embora pra Pasárgada. Org. Emmanuel de Moraes, 4. ed. Rio de Janeiro: José Olympio, 2009.

BARBOSA, João Alexandre. Balanço de João Cabral de Melo Neto. In: . As ilusões da modernidade. São Paulo: Perspectiva, 1986, p.107-137.

. A imitação da forma: uma leitura de João Cabral de Melo Neto. São Paulo: Duas Cidades, 1975.

CAMPOS, Augusto de. Da antiode à antilira. In: Poesia, antipoesia, antropofagia. São Paulo: Cortez \& Moraes, 1978. p. 49-54.

CAMPOS, Haroldo. 0 geômetra engajado. In: Metalinguagem e outras metas. 4. ed. São Paulo: Perspectiva, 1992. p. 77-88.

FERRARA, Lucrécia D’Áléssio. Entre o teatro e a poesia. In: O texto estranho. São Paulo: Perspectiva, 1978. p. 11-19.

LIMA, Luiz Costa. A traição consequente ou a poesia de Cabral. In: . Lira e antilira: Mário, Drummond, Cabral. 2. ed. Rio de Janeiro: Topbooks, 1995. p. 197-331.

MELO NETO, João Cabral. Morte e Vida Severina. In: . Poesias Completas: 19401965. 2. ed. Rio de Janeiro: J. Olympio, 1975. p. 201-241.

NUNES, Benedito. Educação pela pedra. In: . O dorso do tigre. 2. ed. São Paulo: Perspectiva, 1976. p. 265-275. João Cabral de Melo Neto. Petrópolis: Vozes, 1971.

PAVIS, Patrice. Dicionário de teatro. Trad. J. Guinsburg e Maria Lucia Pereira. São Paulo: Perspectiva, 1999.

PEIXOTO, Marta. Poesia com coisas (Uma leitura de João Cabral de Melo Neto). São Paulo: Perspectiva, 1983.

QUEIROZ, Rachel. O Quinze. 56. ed. São Paulo: Siciliano, 1993.

SAMPAIO, Maria Lucia Pinheiro. Processos retóricos na obra de João Cabral de Melo Neto. São Paulo: Hucitec, 1978. 
SARAIVA, Antônio José. Gil Vicente e o fim do teatro medieval. 2. ed. Lisboa: EuropaAmérica, 1985.

SECCHIN, Antonio Carlos. João Cabral: a poesia do menos. São Paulo: Duas Cidades, 1985.

SEGOLIN, Fernando. Personagem e anti-personagem. 3aㅗ ed. São Paulo: Olho D’Água, 2006.

SERRONI, José Carlos. Cenografia brasileira: notas de um cenógrafo. São Paulo: Edições SESC, 2013.

SPINA, Segismundo. Obras-primas do teatro vicentino. 4. ed. São Paulo: DIFEL, 1983.

Recebido em junho de 2014.

Aceito em outubro de 2014. 